\title{
Determination of Cichoric Acid as a Biomarker in Echinacea Purpurea Cultivated in Iran Using High Performance Liquid Chromatography
}

\author{
Javad Zolgharnein $^{1^{*}}$, Ali Niazi ${ }^{2}$, Somieh Afiuni-Zadeh ${ }^{1}$, Khosrow Zamani $^{1}$ \\ ${ }^{1}$ Department of Chemistry, Faculty of Science, University of Arak, Arak, I.R. Iran \\ ${ }^{2}$ Department of Chemistry, Faculty of Science, Azad University of Arak, Arak, I.R. Iran \\ E-mail: J-Zolgharnein@araku.ac.ir \\ Received March 4, 2010; revised April 29, 2010; accepted May 10, 2010
}

\begin{abstract}
Echinacea purpurea (Purple coneflower) is an immunostimulating drug, containing multiple substances. The most important substance in activity is polysaccharide, caffeic acid derivatives (cichoric acid), alkamides and glycoproteins. It is not clear yet, which substances are responsible for activity. Cichoric acid is an appropriate marker of the quality of Echinacea purpurea containing product, because it has immune stimulatory effects and it is susceptible to degradation. In this study a TLC scanner system and HPLC method has been used for identification and determination of cichoric acid in aerial parts of Echinacea purpurea. The results showed that the cichoric acid content of Echinacea purpurea cultivated in Iran is about $1.50 \pm 0.65 \%(\mathrm{w} / \mathrm{w})$ which is comparable with cichoric acid content in native plants. The local conditions have no significant effect on cichoric acid content as a biomarker of Echinacea purpurea quality.
\end{abstract}

Keywords: Echinacea Purpurea, Cichoric Acid, TLC, HPLC, Iran

\section{Introduction}

Herbal medicine has lower side effects in comparison with chemical drugs. Attention and stimulation for using herbal drugs are increasing in recent years. Systematic study about characteristics properties of herbal drug has been increased. Echinacea purpurea Monech (purple coneflower), originated in the United States of America and was brought to Europe in the late 19th century [1]. Recently, Echinacea purpurea has been cultivated in some parts of Iran (e.g. Isfahan) and used in some herbal drugs [2]. It exhibits antioxidative, antibacterial, antiviral and antifungal activities, but most of all it affects on various immune parameters [3-21]. Because of its immuno-enhancing activity, it has been recently used in AIDS therapy [22]. It is used for treating flu and cold, against which symptomatic treatment is an established procedure

The most important potential active compounds in purple coneflower are polysaccharides, caffeic acid derivatives (especially cichoric acid), alkamides and glycoproteins [6,7]. Cichoric acid is an appropriate marker because it has immune stimulatory effects and is proba- bly the most effective substance in Echinacea purpurea. Climate and cultivation conditions could affect cichoric acid content in Echinacea purpurea. Recently, nevertheless, the lack of studies on the adaptability of the culture, the productivity and the quality of the product was apparent. Various methods for determination of cichoric acid such as HPLC, and capillary electrophoresis have been used [22-31].

In this study, a TLC scanner system and an HPLC method was used for identification and quantification of cichoric acid content in aerial parts of Echinacea purpurea which is cultivated in Iran. The result was compared with native plants in Europe and America.

\section{Experimental}

\subsection{Chemicals}

2-aminoethyl diphenyl borinate (Sigma), caffeic acid, chlorogenic acid and all solvents; methanol, ethyl acetate, formic acid was analytical grade and purchased from Merck. All solvents used for running HPLC, were HPLC grade. Dionized, double distilled water was used. 


\subsection{Samples}

Several different batches of aerial parts of aerated and dried Echinacea purpurea were collected and ground with a $40 \mathrm{~mm}$ mesh to a fine powder. Samples were prepared by solving the powder in methanol/water (70:30) with the ratio of $1 \mathrm{~g}$ in $10 \mathrm{ml}$ using an ultrasonic bath for approximately $5 \mathrm{~min}$ and then filtered. Chlorogenic acid and caffeic acid were dissolved in alcohol/water solutions which are stable at least for 30 hours if light protected.

\subsection{TLC and HPLC}

The CAMAG TLC system with auto sampler and scanner which is controlled by Wincats software was used for identification. The plates were prepared by TLC silica gel HF254 $(5 \mu \mathrm{m})$. The mobile phase composed of anhydrous formic acid, ethyl acetate and water (2:1:17). Sample solution and standard solution were prepared respectively by dissolving $0.5 \mathrm{~g}$ powder in $5 \mathrm{ml}$ solvent and $0.05 \mathrm{mg}$ of caffeic acid and $0.05 \mathrm{mg}$ of chlorogenic acid in $10 \mathrm{ml}$ solvent $25 \mu \mathrm{l}$ of sample solution and $10 \mu \mathrm{l}$ of standard solutions were applied as TLC bands $[31,32]$. For detection of stains under $\mathrm{UV}_{366}$ lamp, 2-amino diphenyl borinate in methanol $(10 \mathrm{mg} / \mathrm{ml})$ was used as reagent which is famous as natural product reagent.

\subsection{High Performance Liquid Chromatography (HPLC)}

The Cecil 1100 HPLC system was used for quantitative assay. This system equipped with a $20 \mu \mathrm{l}$ injection loop, $a_{18}$ Lichrosorb column with $0.25 \mathrm{~m}$ length, and $4.6 \mathrm{~mm}$ diameter and UV-Vis detector which was set at $330 \mathrm{~nm}$. Acetonitrile and phosphate buffer (phosphoric acid/water $(1: 99 \mathrm{~V} / \mathrm{V})$ were used as mobile phases in a gradient elution of solvents with $1.5 \mathrm{ml} / \mathrm{min}$ flow rate according to set programs in EP and USP [31,32]. Sample solution and standard solution were prepared by dissolving 0.25 $\mathrm{mg}$ of powder of sample and $0.47 \mathrm{mg}$ chlorogenic acid in $10 \mathrm{ml}$ solvent respectively. Chlorogenic acid was used as external standard which was cheaper and available in Iran [22].

The percentage of cichoric acid content was calculated by the following equation $[22,31,32]$ :

$$
\mathrm{C}_{\mathrm{u}} \%=100\left(\mathrm{~A}_{\mathrm{u}} \times \mathrm{C}_{\mathrm{s}} \times 0.695\right) /\left(\mathrm{A}_{\mathrm{s}} \times \mathrm{C}_{\mathrm{t}}\right)
$$

where $\mathrm{C}_{\mathrm{u}}$ is the concentration of cichoric acid in sample peak; $A_{u}$, the peak area for cichoric acid; $C_{s}$, the concentration of standard chlorogenic acid solution $(\mathrm{mg} / \mathrm{ml}) ; \mathrm{A}_{\mathrm{s}}$, the peak area for standard chlorogenic acid; $\mathrm{C}_{\mathrm{t}}$, amount of powder in sample solution $(\mathrm{mg} / \mathrm{ml}) ; 0.0695$, the response factor of cichoric acid relative to that of chlorogenic acid. The detector response factor was planned as the ratio of slope of the two calibration curves prepared with standard solutions $[22,31,32]$.

\section{Results and Discussion}

The chemical structures of Cichoric acid (a), Chlorogenic acid (b) and Caffeic acid (c) are shown in Figure 1. Figure 2 shows the image of TLC plate of sample and standard solutions. In the left track, the yellow florescent zones are related to chlorogenic acid $\left(\mathrm{R}_{\mathrm{f}}=0.45\right)$ and caffeic acid $\left(R_{f}=0.84\right)$ contained in the standard solutions. In the right track of TLC plate, the fluorescent zones are related to caftaric acid $\left(\mathrm{R}_{\mathrm{f}}=0.52\right)$ and cichoric acid $\left(\mathrm{R}_{\mathrm{f}}=\right.$ $0.86)$ contained in sample solution. Figure 3, clearly confirmed the presence of cichoric acid and absence of chlorogenic acid in sample solution [31,32].

The chromatograms related to standard and sample are shown in Figures $\mathbf{4}$ and $\mathbf{5}$ respectively. According to literatures the relative retention time for cichoric acid respect to chlorogenic acid is about 2.3 [31]. While the chlorogenic acid peak appears at 8 minute, the cichoric<smiles>O=C(/C=C/c1ccc(O)c(O)c1)O[C@H](C(=O)O)[C@H](OC(=O)/C=C/c1ccc(O)c(O)c1)C(=O)O</smiles>

(a)<smiles>O=C(/C=C/c1ccc(O)c(O)c1)OC1CC(O)(C(=O)O)CC(O)C1O</smiles>

(b)<smiles>O=C(O)/C=C/c1ccc(O)c(O)c1</smiles>

(c)

Figure 1. (a) The structure of Cichoric acid, (b) Chlorogenic acid and (c) Caffeic acid. 


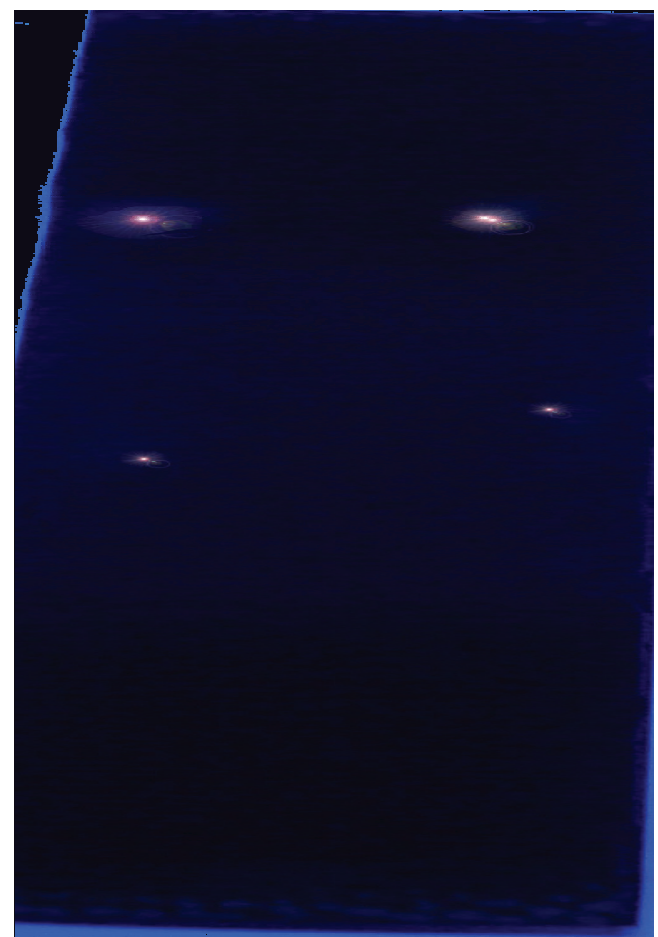

Figure 2. TLC image of sample solution containing caftaric acid and cichoric acid (right track) and standard solution containing chlorogenic acid and caffeic acid (left. track).

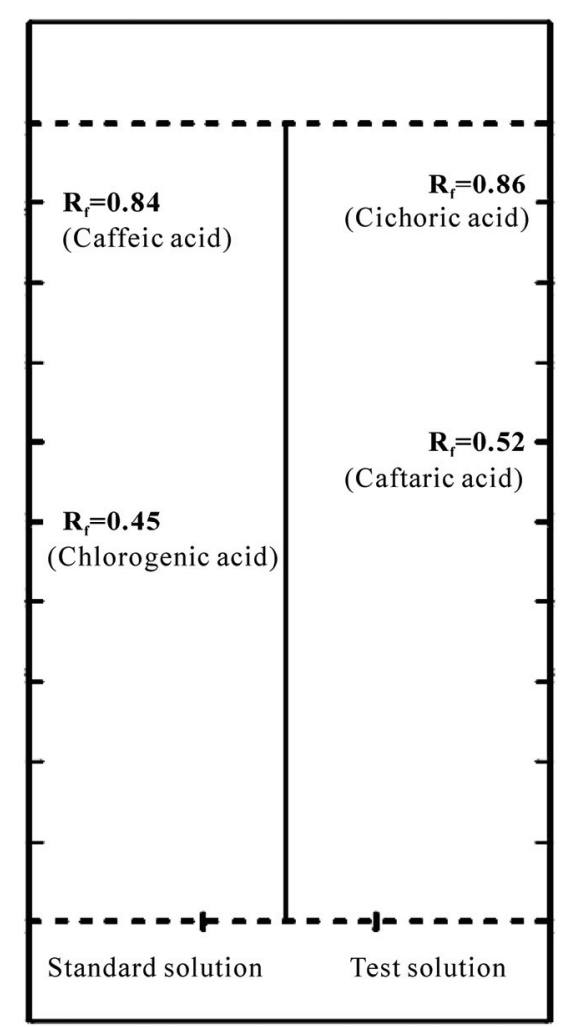

Figure 3. TLC schematic figure of sample containing caftaric acid and cichoric acid (right track) and standard solution containing chlorogenic acid and caffeic acid (left. track).

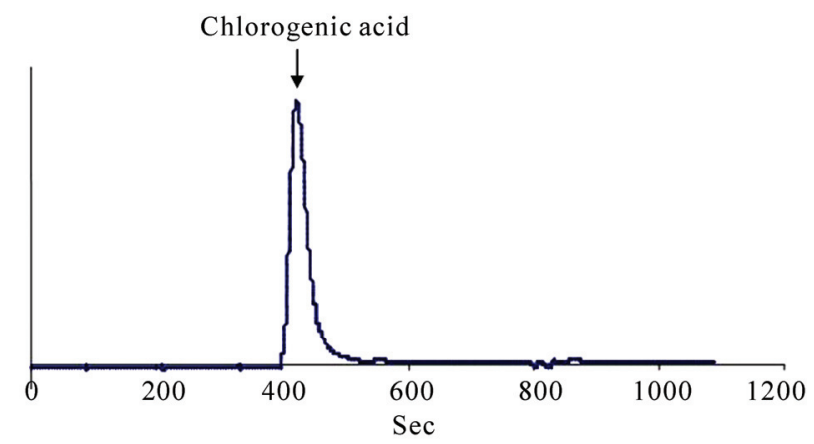

Figure 4. HPLC chromatogram of $0.25 \mathrm{mg} / 5 \mathrm{ml}$ standard solution (chlorogenic acid).

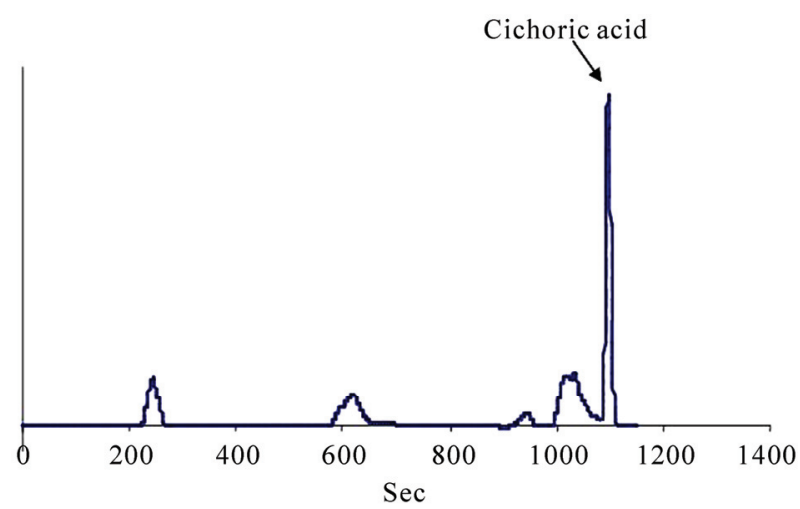

Figure 5. HPLC chromatogram of $2.5 \mathrm{mg} / 10 \mathrm{ml}$ sample solution.

acid peak should appear at about 18 minute. Then the cichoric acid concentration is calculated, based on equation which was mentioned in Equation (1). The HPLC experimental data obtained is shown in Table 1.

Calculation results shows that cichoric acid concentration is about $(1.5 \pm 0.65) \%(\mathrm{w} / \mathrm{w})$ in the aerial parts of Echinacea purpurea cultivated in Iran. This amount show good agreement with native plant $(1.2-3.1) \%$. This means that the local conditions of cultivation of this herbal drug have no significant effects on its medicine marker.

Table 1. The HPLC experimental data.

\begin{tabular}{cc}
\hline $\mathrm{C}_{\mathrm{s}}$ & $0.047 \mathrm{mg} / \mathrm{mL}$ \\
$\mathrm{C}_{\mathrm{t}}$ & $2.5 \mathrm{mg} / \mathrm{mL}$ \\
$\mathrm{A}_{\mathrm{s}}$ & 4934823 \\
$\mathrm{~A}_{\mathrm{u}}$ & 5977445 \\
$\mathrm{C}_{\mathrm{u}}$ & $1.58 \%$ \\
$\mathrm{SD}$ & $\pm 0.65 \%$ \\
\hline
\end{tabular}

$\mathrm{C}_{\mathrm{s}}$ : concentration of standard solution (chlorogenic acid). $\mathrm{A}_{\mathrm{s}}$ : the peak area for chlorogenic acid.

$\mathrm{C}_{\mathrm{t}}$ concentration of sample solution containing cichoric acid.

$\mathrm{A}_{\mathrm{u}}$ : the peak area for cichoric acid.

$\mathrm{C}_{\mathrm{u}}$ : concentration of cichoric acid in sample solution.

SD: Standard deviation $(\mathrm{n}=3)$. 


\section{Conclusions}

The qualitative and quantitative analysis of Cichoric acid content in Echinacea purpurea which is cultivated in Iran has been studied. Cichoric acid is probably one of the most important markers for controlling the quality of drugs containing Echinacea purpurea. The results showed that the cichoric acid content of Echinacea purpurea is appropriate for drugs in comparison with native plants.

\section{References}

[1] R. L. Mc Gregor, "The taxonomy of the genus Echinacea (Compositae)," University of Kansas Science Bulletin, Vol. 48, No. 4, 1968, pp. 113-142.

[2] S. Soudi, S. M. Hashemi, A. Z. Hosseini, A. Ghaemi and M. A. Jafarabadi, "Antileishmanial Effect of Echinacea purpurea Root Extract Cultivated in Iran," Iranian Journal of Pharmaceutical Research, Vol. 6, No. 2, 2007, pp. 147-149.

[3] M. Blumenthal, "The Complete German Commission E Monographs", American Botanical Council, Austin, 1999.

[4] S. Percival, "Use of Echinacea in Medicine," Biochemical Pharmacology, Vol. 60, No. 2, 2002, pp. 155-158.

[5] R. Bauer, "Standardisierung von Echinacea-purpureaPrebsaft auf Chicoriensaure und Alkamide," Zeitschrift für Phytotherapie, Vol. 18, 1997, p. 270.

[6] R. Bauer and H. Wagner, "Echinacea, Handbuch fur Ärzte," Apotheker und Andere Naturwissenschaftler, Wissenschaftliche Verlagsgessellschaft GmbH, Stuttgart, 1990, p.182.

[7] M. Chavez, L. Chavez and P. I. Chavez, "Echinacea," Hospital Pharmacy, Vol. 33, 1998, p. 180.

[8] "WHO Monographs on Selected Medicinal Plants," World Health Organization, Geneva, Vol. 1, 1999, p. 136.

[9] "Graphs on the Medicinal Uses of Plant Drugs," Fascicule 6, Echinaceae Purpureae Herba (Purple Coneflower Herb), European Scientific Cooperative on Phytotherapy (ESCOP), 1999, p. 10.

[10] R. Bauer, W. Dorsch, H. J. Gabius, S. Gabius, H. D. Reuter and C. Siegers, "Pharmazeutische Qualität, Standardisierung und Normierung von Phytopharmaka," Zeitschrift für Phytotherapie, Vol. 15, 1994, p.82.

[11] S. E. Binns, J. Hudson, S. Merali, et al., "Antiviral Activitiy of Characterized Extracts from Echinacea sp. (Heliantheae: Asteraceae) against Herpes Simplex Virus Type 1," Planta Medica, Vol. 68, No. 9, 2002, pp. 780-783.

[12] R. M. Facino, M. Carini, G. Aldini, et al., "Echinacoside and Caffeoyl Conjugates Protect Collagen from Free Radical-Induced Degradation: A Potential Use of Echinacea Extracts in the Prevention of Skin Photodamage," Planta Medica, Vol. 61, No. 6, 1995, pp. 510-514.

[13] M. Nardini, M. D. Aquino, G. Tomassi, et al., "Inhibition of Human Low-Density Lipoprotein Oxidation by Caffeic Acid and Other Hydroxycinnamic Acid Derivatives, Free
Radical," Biology Medicine, Vol. 19, No. 5, 1995, pp. 541-552.

[14] B. D. Sloley, L. J. Urichuk, C. Tywin, et al., "Comparison of Chemical Components and Antioxidants Capacity of Different Echinacea Species," Journal of Pharmacy and Pharmacology, Vol. 53, No. 6, 2001, pp. 849-857.

[15] M. Nardini, F. Natella, V. Gentili, et al., "Effect of Caffeic Acid Dietary Supplementation on the Antioxidant Defense System in Rat: An in Vivo Study," Archives of Biochemistry and Biophysics, Vol. 42, No. 1, 1997, pp. 157-160.

[16] J. Roesler, A. Emmendorfer, C. Steinmuller, et al., “Application of Purified Polysaccharides from Cell Cultures of the Plant Echinacea Purpurea to Mice Mediates Protection against Systemic Infections with Listeria Monocytogenes and Candida Albicans," International Journal of Immunopharmacology, Vol. 13, No. 1, 1991, pp. 27 37.

[17] H. Wagner, H. Stuppner, W. Schafer, et al., "Immunologically Active Polysaccharides of Echinacea Purpurea Cell Cultures," Phytochemistry, Vol. 27, No. 1, 1988, pp. 119-126.

[18] E. Speroni, P. Govoni, S. Guizzardi, et al., "AntiInfiammatory and Cicatrizing Activity of E. Pallid Nutt Root Extract," Journal Ethnopharmacology, Vol. 2, No. 79, 2001, p. 265.

[19] A. Wacker and W. Hilbig, "Virus-Inhibition by Echinacea Purpurea," Planta Medica, Vol. 33, 1978, p. 89.

[20] G. Mazza and T. Cottrell, "Volatile Components of Roots, Stems, Leaves, and Flowers of Echinacea Species," Journal of Agricultural Food Chemistry, Vol. 47, No. 8, 1999, pp. 3081-3085.

[21] A. Cheminat, R. Zawatzky, H. Becker, et al., "Caffeoyl Conjugates from Echinacea Species: Atructures and Biological Activity," Phytochemistry, Vol. 27, No. 9, 1988, p. 2787-2794.

[22] B. Mancek and S. Kreft, "Determination of Cichoric Acid Content in Dried Press Juice of Purple Coneflower (Echinacea Purpurea) with Capillary Electrophoresis," Talanta, Vol. 66, No. 5, 2005, pp. 1094-1097.

[23] J. A. Duke, Handbook of Medicinal Herbs, 2nd Edition, CRC Press, Boca Raton, 2002.

[24] P. Molgaard, S. Johnsen, P. Christensen and C. Cornett, "HPLC Method Validated for the Simultaneous Analysis of Cichoric Acid and Alkamides in Echinacea Purpurea Plants and Products," Journal of Agriculture and Food Chemistry, Vol. 51, No. 24, 2003, pp. 6922-6933.

[25] X. B. Luo, B. Chen, S. Yao and Z. J. G. Zeng, "Simultaneous Analysis of Caffeic Acid Derivatives and Alkamides in Roots and Extracts of Echinacea Purpurea by High-Performance Liquid Chromatography-Photodiode Array Detection-Electrospray Mass Spectrometry," Journal of Chromatography A, Vol. 986, No. 1, 2003, pp. 73- 81 .

[26] S. Gocan, L. Radu and M. Hdarauga, "Simultaneous Analysis by High Performance Liquid Chromatography of Hydrophilic Compounds and Lipophilic Compounds 
(Alkamides) from Pharmaceutical Preparations of Echinacea Purpure Root," Chromatographia, Vol. 57, No. 910, 2003, p. 677.

[27] M. Laasonen, T. Wennberg, T. Harmia-Pulkkinen and H. Vuorela, "Simultaneous Analysis of Alkamides and Caffeic Acid Derivatives for the Identification of Echinacea Purpurea, Echinacea Angustifolia, Echinacea Pallida and Parthenium Integrifolium Roots," Planta Medica, Vol. 68, No. 6, 2002, pp. 572-574.

[28] G. W. Schieffer and M. Kohn, "HPLC Assay of Echinacea Purpurea/Goldeseal (Hydrastis Canadensis) Combination Formulations for Phenolic Acid, Alkemides and Alkaloids," Journal of Liquid Chromatography Related
Technology, Vol. 25, No. 2, 2002, p. 263.

[29] G. Giancaspro, "Echinacea Purpurea Aerial Parts," Pharmacopeial Forum, Vol. 30, 2004, p. 557.

[30] R. Pomponio, R. Gotti, M. Hudaib, et al., "Analysis of Phenolic Acids by Micellar Electrokinetic Chromatography: Application to Echinacea Purpurea Plant Extracts," Journal of Chromatogrphy A, Vol. 954, No. 1-2, 2002, pp. 239-247.

[31] The European Pharmacopoeia Forum (Pharmeuropa), Vol. 16, 2004, p. 545.

[32] United States Pharmacopoeia (USP), 28-NF 23, 2005. 